\title{
PENDIDIKAN AGAMA KRISTEN DALAM MATIUS 28:19-20
}

\author{
Yosia Belo, M.Pd.K. \\ Sekolah Tinggi Teologi Injili Arastamar Jakarta
}

\begin{abstract}
This article talks about a biblical study of the text of Matthew 28: 19-20. This study was conducted to gain an understanding of Christian Religious Education in Matthew 28: 19-20. So that every PAK teacher can apply in applying and teaching students.

Keywords: Christian Religious Education, Matthew, Great Commission
\end{abstract}

\begin{abstract}
Abstrak: Artikel ini berbicara tentang kajian biblika terhadap teks Matius 28:19-20. Kajian ini dilakukan untuk mendapatkan pemahaman tentang Pendidikan Agama Kristen dalam Matius 28:19-20. Supaya dapat diterapkan oleh setiap guru PAK dalam menerapkan dan melakukan pengajaran terhadap peserta didik.
\end{abstract}

Kata Kunci: Pendidikan Agama Kristen, Matius, Amanat Agung

\section{PENDAHULUAN}

Pendidikan adalah salah satu hal terpenting dalam kehidupan setiap manusia. Oleh karena melalui pendidikan, setiap orang dapat mengetahui banyak hal, banyak pengetahuan dan banyak pengalaman. Namun apabila pendidikan hanya mementingkan pengetahuan saja, maka pendidikan hanya akan menghasilkan manusia yang pintar namun memiliki moral yang tidak baik.

Beberapa minggu yang lalu, kita baru saja dihebohkan oleh pemberitaan media tentang seorang WNI di Inggris (kota Manchester) yang sedang studi lanjut berinisial "RS" yang divonis penjara seumur hidup karena terbukti bersalah telah memperkosa lebih dari 100 pria di Inggris. Meskipun RS merupakan seorang Kristen yang taat beribadah, tetapi kemungkinan besar dia tidak bertumbuh dalam didikan pendidikan Kristen secara benar. Meskipun pada beberapa kesempatan sang ibu mengatakan bahwa RS adalah anak yang baik dan rajin beribadah.1 Lalu, di mana letak kesalahannya? Bisa saja RS lebih

${ }^{1}$ Ibu Reynhard menggambarkannya sebagai "anak yang baik, rajin beribadah, rajin ke gereja."(Artikel ini telah tayang di Kompas.com dengan judul "Di Mata Ibu, Reynhard Sinaga adalah Anak yang Baik dan Rajin Beribadah", https://internasional.kompas.com/read/2020/01/07/12472331/di-mata-ibu-reynhard-sinaga-adalahanak-yang-baik-dan-rajin-beribadah?page=all.) Editor : Ardi Priyatno Utomo 
mengutamakan pendidikan sekuler yang akan memperlengkapi dia secara pengetahuan namun tidak memperbaiki moralnya, sehingga dia jatuh dalam penyimpangan seksual.

Seyogyanya Pendidikan Agama Kristen berdasarkan Alkitab, dan menjadikan Alkitab sebagai sumber filosofis serta dasar menetapkan kurikulum yang dirumuskan di dalamnya. Menurut Ferry Yang, "Pendidikan Kristen memiliki bobot yang jauh lebih dalam daripada pendidikan sekuler atau pendidikan secara umum".2 Pendapat di atas kembali dipertegas oleh Louis Berkhof dan Cornelius van Til dengan berkata,

Jika pendidikan Kristen berbasiskan kebenaran firman Tuhan, maka pendidikan sekuler dibangun di atas pendekatan ateistik. Akibatnya, terjadi perbedaan konsep yang mutlak berbeda. Alkitab mengungkapkan bahwa manusia adalah ciptaan Allah yang harus memuliakan Allah, sehingga pendidikan tidak hanya berbicara tentang ilmu pengetahuan, tetapi juga moralitas dan integritas hidup yang sesuai dengan panggilan dan tuntutan moralitas Allah.3

Berdasarkan apa yang dikemukakan di atas, maka jelas sekali diungkapkan kepada kita bahwa seyogyanya pendidikan Kristen harus menjadikan setiap peserta didik percaya kepada Allah dan bertumbuh dalam pengenalan akan Tuhan Yesus serta mengubah totalitas kehidupan mereka. Di mana Pendidikan Kristen tidak hanya sekadar memberikan pengetahuan namun juga mentransformasi kehidupan sehingga senantiasa mempermuliakan Tuhan. Atau dengan kata lain, pendidikan Kristen harus membawa setiap peserta didik menjadi murid Kristus, seperti yang terdapat dalam Matius 28:19-20.

Matius 28:19-20 lebih dikenal dengan Amanat Agung (Great Commission) atau perintah Yesus untuk pergi memberitakan Injil kepada seluruh bangsa yang ada di dalam dunia ini. Namun ada hal yang menarik serta penting dalam dua ayat ini. Yakni munculnya ungkapan "murid" dan "ajarlah". Itulah sebabnya, Ferry Yang berkata, "Amanat Agung seringkali disalah mengerti hanya sebagai amanat yang sifatnya memberikan penginjilan saja. Tetapi pengertian ini salah. Tentu saja penginjilan masuk di dalamnya. Tetapi penginjilan bukanlah satusatunya hal yang disebutkan Tuhan Yesus. Kalau kita menilik amanat dari Amanat Agung yang diberikan Tuhan Yesus, justru titik beratnya ada pada hal menjadikan semua bangsa murid dari Tuhan Yesus Kristus".4

2 Ferry Yang, Pendidikan Kristen, (Surabaya: Momentum, 2018), hlm.6.

3 Louis Berkhof dan Cornelius van Til, Foundations of Christian Education, (Surabaya: Momentum, 2008), hlm. I.

${ }^{4}$ Ferry Yang, hlm. 21-22. 
Itulah sebabnya dalam tulisan ini hendak dibahas dan diteliti dengan lebih dalam dan tentu menggunakan pendekatan biblis untuk mendapatkan pemahaman yang benar terhadap makna dari menjadikan semua bangsa murid Kristus dan apa maksud ungkapan "ajarlah mereka...”.

\section{METODE PENELITIAN}

Penelitian ini menggunakan pendekatan kualitatif, secara khusus kajian pustaka. Pendekatan ini diambil untuk memperoleh pemahaman kualitatif yang valid dan komprehensif bagi topik yang dibahas dalam penelitian ini.

\section{PEMBAHASAN MATIUS 28:19-20}

Pada pembahasan Matius 28:19-20 hanya akan difokuskan kepada dua frasa,

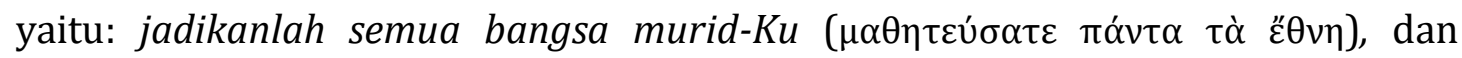
ajarlah mereka melakukan segala sesuatu yang telah Kuperintahkan kepadamu

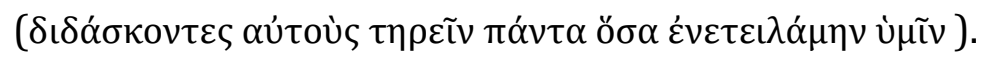

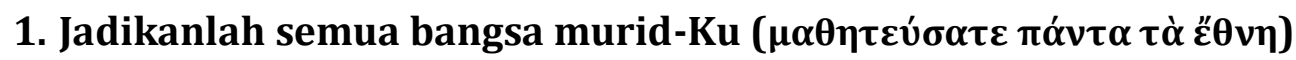

Ungkapan "jadikalanlah semua bangsa murid-Ku" merupakan tindakan yang sangat penting dalam menjalankan Amanat Agung Yesus Kristus. Selain penting, tindakan ini pula wajib dilakukan oleh setiap orang Kristen. Namun pertanyaannya: Bagaimana caranya menjadikan semua bangsa murid Kristus? Dan Siapa saja yang dimaksud dengan semua bangsa dalam konteks ini?

Kata $\mu \alpha \theta \eta \tau \varepsilon u ́ \sigma \alpha \tau \varepsilon$ (mathēteusate) adalah kata kerja imperatif aoris aktiforang kedua jamak. Kata ini berasal dari kata dasar $\mu \alpha \theta \eta \tau \varepsilon v ́ \omega$ (mathēteuō). Hasan Sutanto mengartikan kata ini sebagai "menjadi murid; menjadikan murid".5 Menurut Kittel, kata $\mu \alpha \theta \eta \tau \varepsilon u ́ \omega$ (mathēteuō) berakar dari kata $\mu \alpha v \theta \alpha ́ v \omega$ (manthánō) yang memiliki pengertian dasar (1) "to accustom oneself to something", (2) "to experience," (3) "to learn to know," (4) "to understand," (5) "To learn under instruction ," dan (6) "to receive direction from a deity by oracle."Secara konsisten, penggunaannya mengimplikasikan proses intelektual yang selalu memiliki efek eksternal dan melingkupi inisiatif intelektual sadar dan tak sadar. Kata $\mu \alpha \theta \eta \tau \varepsilon v ́ \omega$ (mathēteuō) dalam penggunaan intransitif memiliki makna "to be or become the pupil". Matius 27:57 mengatakan dengan mengacu Yusuf dari Arimatea; dia dikatakan menjadi murid Yesus. Dalam penggunaan transitif khas (Mat. 13:52; 28:19; Kis. 14:21) PB juga

\footnotetext{
${ }^{5}$ Hasan Sutanto, Perjanjian Baru Interlinear Yunani-Indonesia dan Konkordansi Perjanjian Baru, (Jakarta: Lembaga Alkitab Indonesia, 2003), hlm. 497.
} 
menggunakan istilah "to make disciple". Mungkin dibalik itu ada keyakinan PB bahwa panggilan adalah dasardari pemuridan Yesus.6

Berdasarkan data-data di atas, maka dapat diambil kesimpulan bahwa kata $\mu \alpha \theta \eta \tau \varepsilon u ́ \omega$ (mathēteuō) dalam penggunaan transitif aktif berarti "menjadikan murid", dalam penggunaan transitif pasif berarti "dijadikan murid", sedangkan dalam penggunaan intransitif berarti "menjadi murid". Sesuai ulasan yangdiberikan oleh Kittel, maka Matius 28:19 menggunakan kata ini dalam makna transitif

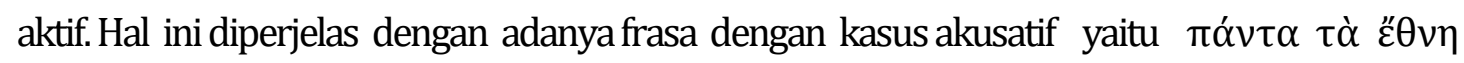
(panta ta ethnē). Kata kerja yang diikuti dengan kasus akusatif menunjukkan bahwa kata kerja tersebut memiliki makna transitif aktif. Dengan demikian kata $\mu \alpha \theta \eta \tau \varepsilon u ́ \sigma \alpha \tau \varepsilon$ (mathēteusate) berarti perintah kepada orang kedua untuk menjadikan murid, atau dalam bahasa Indonesia sepadan dengan“jadikanlah murid".

Kata ini adalah bentuk kedua plural dari $\mu \alpha \theta \eta \tau \varepsilon v ́ \omega$ (matheteuo) dan mempunyai kata dasar mathetes (murid). Sangat menarik, Matius dengan sengaja merubah kata benda "murid" menjadi kata kerja (jadikan murid). Bentuk kata kerja dari kata ini hanya muncul empat kali dalam Perjanjian Baru (Mat. 13:52; 27:57; 28:29; Kis. 14:21).7 Kata ini adalah perintah, baik dilihat bentuk maupun artinya - satusatunya bentuk perintah verbal dalam ayat 16 sampai ayat 20. Inilah penekanan dari Amanat Agung yaitu menjadikan murid orang-orang yang belum mengenal-Nya. Pengertian "mengajar atau memuridkan" di bagian ini adalah berkaitan dengan pengajaran tentang keselamatan yang menuntun orang yang tidak percaya menjadi percaya dan menuntunnya datang kepada Yesus Kristus.

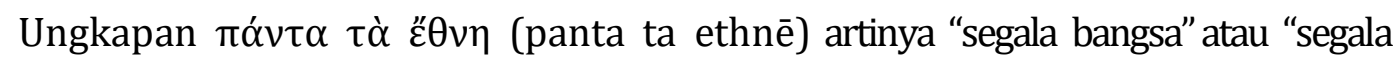
etnis". Frasa ini memberikan pengertian bahwa jangkauan untuk menjadikan murid adalah segala bangsa, yakni semua manusia yang ada di muka bumi. Sehingga anak kalimat

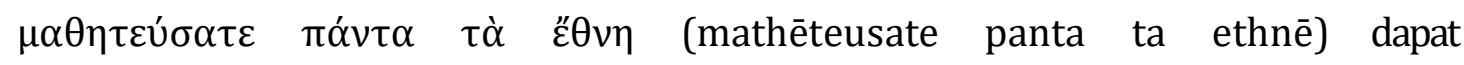
diartikan“Jadikanlah semua bangsa murid." MenurutJohn Piper,

Sekarang kita kembali ke usaha awal kita untuk memahami apa yang Yesus maksudkan di Matius 28:19 ketika Dia berkata "Pergilah dan jadikanlah Panta ta Ethne murid-Ku." Perintah ini memiliki janji keberhasilan yang bertalian di Matius 24:14, "Dan Injil kerajaan ini akan diberitakan di seluruh dunia, sebagai kesaksian kepada semua bangsa (pasin tois ethnesin); dan setelah itu kesudahannya akan datang." Lingkup perintah dan lingkup

${ }_{6}$ Gerhard Kittel, Gerhard Friedrich and Geoffrey William Bromiley, Theological Dictionary of the New Testament, Translation of: Theologisches Worterbuch Zum NeuenTestament. (Grand Rapids, Mich.: W.B. Eerdmans, 1995, c1985), hlm. 522-562.

7 Johannes Verkuyl, dkk., Misi Menurut Perspektif Alkitab, Dasar dan Prinsip Penginjilan Sedunia, (Jakarta: Yayasan Komunikasi Bina Bangsa, 2007), hlm. 74-78. 
janji itu memegang erat-erat arti dari Panta ta Ethne. Kesimpulan saya dari apa yang telah kita lihat di bab ini adalah bahwa seseorang harus benarbenar melawan arus bukti untuk mengartikan kata phrase Panta ta Ethne sebagai "semua orang-orang bukan Yahudi" (atau "semua negeri"). Melainkan, fokus perintah itu adalah memuridkan semua kelompok orang di dunia.8

Bauers Walter mengatakan seperti yang dikutip oleh Adi Putra, "Kata $\varepsilon \dot{\theta} v \tilde{\omega} v$ (ethnon) dapatdipahami dalam beberapa pengertian, yakni: (1) disatukan oleh seseorang melalui pertalian kekeluargaan, budaya, tradisi, negara, dan orang; (2) kelompok orang-orang asing yang spesifik pada sebuah kelompok tertentu: mereka yang tidak termasuk dalam kelompok orang yang menyatakan iman di dalam Allah Israel, bangsa-bangsa, bukan Yahudi, dan bukan orang percaya; orang Kristen non-Israel, umat Kristen yang terdiri dari bangsa-bangsa lain yang terdiri dari beberapa bangsa atau tidak dibatasi hanya kepada orang Israel."9

\section{Ajarlah mereka melakukan segala sesuatu yang telah Kuperintahkan}

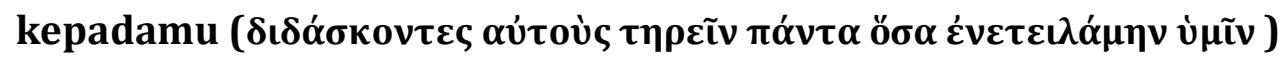

Kata $\delta เ \delta \alpha ́ \sigma \kappa o v \tau \varepsilon \varsigma$ (didaskontes) adalah kata kerja partisipel presen aktif nominatif maskulin orang kedua jamak. Kata iniberasal darikata dasar $\delta ı \delta \alpha ́ \sigma \kappa \omega$ (didaskō). Hasan Sutanto mengartikan kata inisebagai "mengajar; mengajarkan".10 Moulton mengartikan dengan "mengajar(kan); mengajar atauberbicara di muka perkumpulan umum; memerintah; memperingatkan".11

Kata yang digunakan di sini identik dengan kata yang digunakan oleh penulis Injil untuk menjelaskan aktivitas mengajar yang dilakukan oleh Tuhan Yesus selama meyalani di dunia ini. Adi Putra mengatakan,

Apabila memperhatikan penggunaannya dalam 1 Timotius 2:12 maka dapat diartikan dengan mengajar atau berbicara di depan pertemuan/publik. Matius 28:15; Roma 2:21 dan pada teks-teks yang lain, kata ini dipahami dengan mengarahkan dan menegur... Kata $\delta\llcorner\delta \alpha ́ \sigma \kappa \omega$ dapat dipahami atau diartikan: (1) untuk memberitahukan seseorang apa yang harus dilakukan, katakan, menginstruksikan, misalnya yang terdapat dalam Matius 28:15; (2) untuk memberikan instruksi dalam suasana formal dan informal, mengajar seperti dalam Matius 4:23; Mrk. 1:21; Yoh. 7:14; 1 Kor. 4:17; 1 Tim.4:11; 6:2; dll (BDAG 2000, 241). Kata ini dapat dipahami sebagai sebuah tindakan memberitahukan seseorang apa yang harus dilakukan bisa dalam bentuk

\footnotetext{
${ }^{8} \mathrm{https} / / /$ perspektif.co/Memuridkan_Semua_Bangsa//23/01/2020//

${ }^{9}$ http://jurnalbia.com/index.php/bia/article/view/59/31/23/01/2020//

${ }^{10}$ Hasan Sutanto, hlm. 204.

11 Harold K. Moulton, Leksikon Analitis Bahasa Yunani yang Direvisi, (Yogyakarta: Randa Family Press, 2008), hlm. 91.
} 
formal maupun informal, melalui perkataan yang bersifat instruksional atau pun pengajaran.12

Maka dapat dikatakan aktivitas mengajar Tuhan Yesus di wilayah Galilea hendak menegaskan diri-Nya sebagai pengajar yang sejati di mana Dia hendak meluruskan setiap kekeliruan yang ada pada interpretasi Taurat, supaya orang Israel dapat mengerti kehendak Allah yang sebenarnya melalui memahami Hukum Taurat dengan benar - sekaligus orang Israel dapat melihat bahwa continuitas Hukum Taurat dalam konteks penggenapannya sudah ada dalam Pribadi dan Karya Tuhan Yesus. Meskipun dalam pengajaran-Nya, Dia juga kadang-kadang menyinggung kebobrokan orang-orang Farisi dan para ahli Taurat, akan tetapi karena ketika mengajar yang mendengar hanyalah orang banyak dan para murid maka akibatnya Dia kurang mendapat perlawanan atau pertentangan.

Berdasarkan arti dari kata $\delta\llcorner\delta \alpha ́ \sigma \kappa \omega 13$ yang seringkali digunakan oleh penulis Injil untuk menyebutkan aktivitas mengajar Tuhan Yesus, maka penekanannya dalam setiap ajaran-Nya adalah bagaimana bangsa Israel dapat melakukan halhal yang benar, hal-hal yang dikehendaki oleh Allah, dan hal-hal yang berangkat dari pemahaman yang benar - tentu pehamanan terhadap hukum Allah. Hal yang demikian pula yang wajib dilakukan atau diterapkan oleh setiap Gereja dalam menjalankan misi Agung Allah di tengah-tengah dunia ini, yakni: memperbaiki kesalahan dan mengajarkan apa yang Tuhan kehendaki supaya setiap hidup kita dapat mempermuliakan Tuhan.

\section{HASIL: PENDIDIKAN AGAMA KRISTEN DALAM MATIUS 28:19-20}

Setelah menjelaskan Matius 28:19-20 dan memahami maksud atau makna yang termaktub dalam dua ungkapan: "menjadikan murid" dan "ajarlah", maka sekarang kita akan melihat penerapannya dalam konteks Pendidikan Agama Kristen. Sehingga berdasarkan ayat di atas, kita dapat memahami Pendidikan Agama Kristen sebagai berikut:

1. Pendidikan Agama Kristen Bertujuan untuk Memuridkan

Pendidikan Agama Kristen bertujuan untuk memuridkan berarti menjadi setiap peserta didik untuk memahami perintah Allah dan sekaligus melakukannya dalam setiap aspek kehidupannya. Memuridkan atau menjadikan

\footnotetext{
${ }^{12}$ Adi Putra, Misi Yesus Kepada Bangsa-bangsa Lain: Kajian Biblika terhadap Pelayanan Yesus di Galilea Berdasarkan Matius 4:12-17, (Jakarta: Penerbit Vieka Wahana Semesta, 2015), hlm. 60-61.

13 Selama Yesus menjalankan misi-Nya di bumi, secara garis besar pengajaran Yesus menyinggung beberapa aspek seperti: (1) Yesus mengajar tentang etika (Mat. 5-7; Luk. 6:17-49, 11:37, dst.); (2) tentang metafisika atau teologi (Mat.11:25-27; Luk. 10:21-22; Yoh. 6:33-48; 8:58, dst.); (3) tentang sosial (Luk. 14:7-14; 20:19-25; Mat. 19:3-12 dst.); (4) tentang keselamatan / soteriologi (Mat.9:12-13; 11:28-30; 16:24-26; 20:28; Luk. 9:23-24; 14:15-24; 15:1-32; 18:9-14; 19:9-10; Yoh. 10:1-8 dst.); dan (5) tentang eskatologi (Mat. 24:25; Mrk. 13; Luk. 21; Yoh. 14:1-3 dst.)
} 
orang lain menjadi murid Kristus tidak terlepas dari mengajar. Menurut Ferry Yang, "Pekerjaan ini membutuhkan ketekunan. Pekerjaan ini sungguh-sungguh membutuhkan cinta kasih yang besar dari surga untuk boleh mendidik dan mengajar supaya orang-orang yang sudah dilahirkan baru ini boleh menjadi dewasa di dalam Yesus Kristus".14

Mengajar tidak dapat dipisahkan atau dilepaskan dari pemberitaan Injil. Oleh karena tujuan keduanya sama, yakni untuk menjadikan semua orang menjadi murid Kristus. Itulah sebabnya, tidak dapat dielakkan bahwa dalam Pendidikan Agama Kristen, setiap guru PAK harus dan wajib menempatkan Alkitab sebagai kunci, sentral dan kunci pengajaran. E.G. Homrighausen dan I.H. Enklaar mengatakan, “...Jelaslah sudah bahwa Alkitab merupakan pusat dan intipati seluruh PAK. Sebagai orang Kristen injili memang kita mengutamakan dan menitikberatkan pelajaran Alkitab dalam pengajaran agama yang kita berikan".15 Apa yang dikemukakan oleh Homrighausen dan Enklaar di atas cukup beralasan karena memang hanya Alkitab atau firman Tuhan yang dapat membuat seseorang mengerti kehendak Allah dan melakukannya dalam setiap kehidupannya.

Tidak mungkin seseorang dapat menjadi murid Kristus apabila dia sama sekali tidak mengetahui dan mengerti isi Firman Tuhan. Dan dalam konteks mengajarkan Alkitab maka itu merupakan tugas guru-guru Pendidikan Agama Kristen. Proses mengajarkan pendidikan agama Kristen yang berlandaskan Alkitab disebut proses menjadikan murid Kristus.

\section{Pendidikan Agama Kristen Memperbaiki Kekeliruan dan Menuntun kepada} Kebenaran

Oleh karena Pendidikan Agama Kristen (PAK) didasarkan dan berlandaskan pada Alkitab atau Firman Tuhan, maka sudah sepantasnya apabila dikatakan bahwa Pendidikan Agama Kristen dapat memperbaiki kekeliruan dan menuntun kepada kebenaran.

Memperbaiki kekeliruan berarti menyadarkan seseorang akan dosa dan membuat orang itu untuk tidak mau dan menolak untuk melakukan dosa. Tidak cukup sampai di situ, memperbaiki kekeliruan juga dapat membuat seseorang meninggalkan perbuatan-perbuatan dosa dan selanjutnya akan hidup dalam terang kasih dan persekutuan di dalam Kristus.

Menuntun kepada kebenaran berarti membawa seseorang untuk lebih mengenal Yesus Kristus. Memahami kasih-Nya, memahami keadilan-Nya, memahami kekudusan-Nya dan memahami setiap hal yang dikehendaki untuk

\footnotetext{
${ }^{14}$ Ferry Yang, hlm. 35. hlm.61.

15 E. G. Homrighausen dan I.H. Enklaar, Pendidikan Agama Kristen, (Jakarta: BPK Gunung Mulia, 2015),
} 
kita lakukan. Dan perlu untuk dicatat, bahwa semuanya itu hanya dapat diperoleh di dalam Alkitab. Orang yang sudah mengenal kebenaran akan secara otomatis akan selalu mencintainya dan selalu berkomitmen untuk melakukannya. Dan di sinilah peran sentral Pendidikan Agama Kristen diperlukan, karena hanya melaluinya setiap orang dapat memperbaiki kekeliruannya dan dituntun kepada kebenaran.

\section{Pendidikan Agama Kristen adalah Amanat Agung (Great Commission)}

Apabila selama ini kita beranggapan bahwa amanat agung hanyalah penginjilan, maka itu adalah sebuah kekeliruan yang besar. Mengapa? Karena mengajar juga merupakan amanat agung. Seperti yang telah dikemukakan oleh Ferry Yang bahwa tema sentral dari amanat agung dalam Matius 28:19-20 adalah memuridkan atau menjadikan semua bangsa murid Kristus. Fakta inilah yang kemudian mendasari poin ini untuk mengatakan bahwa pendidikan agama kristen adalah amanat agung.

Alasan lainnya mengapa pendidikan agama Kristen disebut sebagai amanat agung karena ini juga merupakan perintah langsung dari Yesus. Karena ini adalah sebuah perintah, maka wajib untuk dilakukan alias tidak bisa disepelehkan dan dikendorkan. Mengapa? Karena yang memberikan perintah adalah seseorang yang Agung, yaitu: Tuhan Yesus sendiri.

Dan karena ini merupakan amanat agung, maka pendidikan agama Kristen atau memuridkan juga merupakan aktivitas yang dilakukan oleh gereja dalam rangka mengkomunikasikan karya penyelamatan Allah yang telah dikerjakan dalam Tuhan Yesus Kristus kepada semua bangsa.

\section{KESIMPULAN}

Setelah melalui pembahasan panjang-lebar tentang topik ini, maka dapat dikemukakan beberapa kesimpulan sebagai berikut:

1. Matius 28:19-20 bukan hanya tentang penginjilan saja, melainkan juga tentang mengajar atau memuridkan. Bahkan isu tentang memuridkan jauh lebih sentral dan lebih dominan dalam dua ayat di atas.

2. Pendidikan agama Kristen dalam Matius 28:19-20 dapat dipahami bahwa PAK bertujuan untuk memuridkan, PAK berarti untuk memperbaiki kekeliruan dan menuntun kepada kebenaran, dan PAK adalah Amanat Agung.

3. Oleh karena PAK adalah amanat agung maka PAK juga sangat penting dan harus dilakukan sepenting memberitakan Injil. Atau mungkin lebih jelasnya adalah penginjilan dan mengajar harus berjalan bersama-sama. 


\section{REFERENSI}

https://internasional.kompas.com/read/2020/01/07/12472331/di-mata-ibureynhard-sinaga-adalah-anak-yang-baik-dan-rajin-beribadah?page=all.) Editor : Ardi Priyatno Utomo

Ferry Yang, Pendidikan Kristen, Surabaya: Momentum, 2018.

Louis Berkhof dan Cornelius van Til, Foundations of Christian Education, Surabaya: Momentum, 2008.

Hasan Sutanto, Perjanjian Baru Interlinear Yunani-Indonesia dan Konkordansi Perjanjian Baru, Jakarta: Lembaga Alkitab Indonesia, 2003.

Gerhard Kittel, Gerhard Friedrich and Geoffrey William Bromiley, Theological Dictionary of the New Testament, Translation of: Theologisches Worterbuch Zum NeuenTestament, Grand Rapids, Mich.: W.B. Eerdmans, 1995, c1985. Johannes Verkuyl, dkk., Misi Menurut Perspektif Alkitab, Dasar dan Prinsip Penginjilan Sedunia, Jakarta: Yayasan Komunikasi Bina Bangsa, 2007. https://perspektif.co/Memuridkan_Semua_Bangsa//23/01/2020// http://jurnalbia.com/index.php/bia/article/view/59/31/23/01/2020// Harold K. Moulton, Leksikon Analitis Bahasa Yunani yang Direvisi, (Yogyakarta: Randa Family Press, 2008.

Adi Putra, Misi Yesus Kepada Bangsa-bangsa Lain: Kajian Biblika terhadap Pelayanan Yesus di Galilea Berdasarkan Matius 4:12-17, Jakarta: Penerbit Vieka Wahana Semesta, 2015.

E. G. Homrighausen dan I.H. Enklaar, Pendidikan Agama Kristen, Jakarta: BPK Gunung Mulia, 2015. 